\title{
Toward Closing a Loophole: Recovering Rare Earth Elements from Uranium Metallurgical Process Tailings
}

\author{
JAMES VAUGHAN (D), ${ }^{1,6}$ KATE TUNGPALAN,${ }^{2}$ ANITA PARBHAKAR-FOX (1) ${ }^{2}$ \\ WENG FU (1), ${ }^{1}$ EMMA J. GAGEN $(1),{ }^{4,5}$ PHILIP NTI NKRUMAH (1), ${ }^{3}$ \\ GORDON SOUTHAM $\mathbb{1 0},{ }^{4}$ ANTONY VAN DER ENT (1) ${ }^{3}$ \\ PETER D. ERSKINE (i), ${ }^{3}$ PAUL GOW (i), ${ }^{2}$ and RICK VALENTA (i) ${ }^{2}$ \\ 1.-School of Chemical Engineering, The University of Queensland, Brisbane, QLD, Australia. \\ 2.-W.H. Bryan Mining \& Geology Research Centre, Sustainable Minerals Institute, The \\ University of Queensland, Brisbane, QLD, Australia. 3.-Centre for Mined Land Rehabilitation, \\ Sustainable Minerals Institute, The University of Queensland, Brisbane, QLD, Australia. \\ 4.-School of Earth and Environmental Sciences, The University of Queensland, \\ Brisbane, QLD, Australia. 5.-Australian Centre for Ecogenomics, School of Chemistry and \\ Molecular Biosciences, The University of Queensland, Brisbane, QLD, Australia. \\ 6.-e-mail: james.vaughan@uq.edu.au
}

Rare earth elements are increasingly required for use in modern high-tech components, and primary production is necessary to meet the demand. Reprocessing legacy metallurgical tailings is advantageous, as the material has already been mined, beneficiated, upgraded, and contained in a single accessible location. The Mary Kathleen uranium process tailings in Queensland, Australia, provides an opportunity for this. The geology and historic process methods for the Mary Kathleen uranium mine are described along with known characteristics of the tailings material. Conventional and alternative REE processing options are reviewed, including phyto-extraction and other bio-technologies. Approaches to determining the appropriate pathway forward for Mary Kathleen tailings are then discussed.

\section{INTRODUCTION}

The demand for rare earth elements (REE) has increased significantly over the last decade, with global rare earth oxide (REO) production increasing markedly over the last 2 years from $132,000 \mathrm{t}$ in 2017 to $210,000 \mathrm{t}$ in $2019 .^{1}$ This production increase is drive by the need for REE in high-technology equipment, particularly in the low-carbon energy industry, but also in auto catalysts and digital technologies. For example, neodymium (Nd), dysprosium (Dy), and praseodymium (Pr) are utilized to manufacture permanent magnets that can withstand high temperatures, and $\mathrm{Pr}$, gadolinium (Gd), europium (Eu) and erbium (Er) are used as nanoparticle-based materials to enhance power conversion efficiencies. Lanthanum (La), cerium (Ce), and $\mathrm{Nd}$ are commonly used as stabilizers in catalytic compounds (e.g., automotive catalysts) and $\mathrm{Eu}$, terbium $(\mathrm{Tb})$, and yttrium $(\mathrm{Y})$ to manufacture video screens. ${ }^{2,3}$

(Received August 5, 2020; accepted October 16, 2020;

published online November 16, 2020)
REE are mined from a variety of mineral deposit types located throughout the world. The majority of global REE production comes from China, which produced $132,000 \mathrm{t}$ of REO ( $63 \%$ of the 2019 global total production), with the USA producing $12 \%$, Myanmar $10.5 \%$, and Australia 10\%. ${ }^{1}$ China currently accounts for $95 \%$ of global production of rare earths (about 90\% of REE used in the USA) and domestic industry consumes about $60 \%$. The Bayan Obo mine situated in Inner Mongolia supplies half of the total production in China. ${ }^{4}$ For REE production in Australia, the Mount Weld deposit, which is located in the near-surface weathered zone (laterite) of a carbonatite complex, ${ }^{5}$ produced $18,600 \mathrm{t}$ of REO in 2018. Other sources of REE production include the ion adsorption clay deposits of southern China, and deposits elsewhere associated with alkaline igneous rocks, laterites, and other hydrothermal deposits. China, Brazil, and Vietnam host the largest proportion of the world's REE resources, with $38 \%, 19 \%$, and $19 \%$, respectively. Recycling REE is not common, with only around $1 \%$ of REE recycled from end-products, typically from 
permanent magnets, fluorescent lighting, batteries, and the REE used as catalysts within the chemical industry. ${ }^{6}$

As demand increases, an emphasis on the extraction of REE as a by-product from active mining activities or through reclamation of historic mine waste, is anticipated. ${ }^{7,8}$ The combination of increased demand and low recycling rates means that new primary production will be required. Examples of operations where REE are not, or were not, extracted from REE-rich ores include the currently operating Olympic Dam $\mathrm{Cu}-\mathrm{Au}-\mathrm{Ag}-\mathrm{U}$ mine in South Australia, ${ }^{9,10}$ the Kiruna iron ore mine in northern Sweden, ${ }^{11}$ and the historic Mary Kathleen mine in Queensland which operated between 1958 and 1982 and is the focus of this review. These deposits all host REE-rich metallurgical process tailings from which the REE has not been extracted.

Reprocessing tailings can be advantageous in terms of reduced capital and operating costs for extraction, relative to the establishment of new mining operations. The ore has already been mined, crushed, and milled, removing a large component of pre-extraction costs, the REE are pre-concentrated, and the material is relatively homogenous in terms of grain size and mineral composition, and is located near the surface. The material is also typically stored in one location on a site that has already been the subject of mining activity disturbance. If properly planned and executed, extraction of REE from historic metallurgical process tailings can form part of the remediation of these sites. There can be different challenges, for example, accessing the material may be difficult due to the lower stability of the site compared with hard rock deposits.

This paper begins with a description of the geology of the Mary Kathleen U deposit and the tailings. The historical tailings at Mary Kathleen are classified as one of the world's 25 highest-grade REE deposits. ${ }^{12,13}$ The conventional processing of REE and alternative processing technologies are reviewed. A link is then made between the features of the Mary Kathleen tailings and the implications for potential reprocessing technologies.

\section{MARY KATHLEEN}

The Mary Kathleen U-REE deposit is located approximately $60 \mathrm{~km}$ east of Mount Isa. The mineralization is hosted by a garnet-diopside skarn within a mixed sedimentary sequence, including calc-silicate, impure marble, cobble and boulder conglomerate, mica schist and quartzite, ${ }^{5,14}$ and an intrusive rock, variably described as a monzonite or diorite that hosts approximately $80 \%$ of the ore. ${ }^{15}$

The host skarn system is interpreted as related to the Burstall Granite, which outcrops $2 \mathrm{~km}$ to the east of the deposit and has an age of approximately 1740-1730 Ma. ${ }^{16}$ However, the U and REE mineralization was emplaced as part of a hydrothermal overprint during the late stage of the Isan Orogeny deformation and metamorphic event at approximately $1550-1530 \mathrm{Ma},{ }^{16,17}$ representing an overprint on the older skarn system.

The predominant uranium mineral is uraninite, and the key REE minerals are allanite, $(\mathrm{Ce}, \mathrm{Ca}, \mathrm{Y},-$ $\mathrm{La})_{2}(\mathrm{Al}, \mathrm{Fe})_{3}\left(\mathrm{SiO}_{4}\right)_{3}(\mathrm{OH})$, and stillwellite, (Ce,La,$\mathrm{Ca}) \mathrm{BSiO}_{5}$, typically associated with garnet, pyroxene, and apatite. ${ }^{5,18}$ The major gangue minerals within the ore include garnet and clinopyroxene, together with the key accessory minerals, including calcite, apatite, hornblende, prehnite, scapolite, and plagioclase. The sulfides are dominated by pyrrhotite with lesser amounts of chalcopyrite, pyrite, and other base metal sulfides. ${ }^{15}$ The ore is strongly enriched in light (L)REE, mainly La and Ce, which comprise about $85 \%$ of the total REE content, with minor $\mathrm{Nd}, \mathrm{Pr}$, and samarium (Sm). ${ }^{19}$

Mary Kathleen was operated by Mary Kathleen Uranium Limited as an open cut mine in two phases: 1958-1963 and 1976-1982. A total of $7532 \mathrm{t}$ of $\mathrm{U}$ ( $8882 \mathrm{t}$ of $\mathrm{U}_{3} \mathrm{O}_{8}$ ) was produced during the mine lifetime, with approximately $45 \%$ in the first phase of operation. ${ }^{15}$ The pre-mining mineral resource at Mary Kathleen comprised 9.5 Mt @ $0.13 \% \mathrm{U}_{3} \mathrm{O}_{8}{ }^{20}$ and $9.2 \mathrm{Mt}$ of ore was processed during the lifetime of the mine. The mine was closed almost 4 decades ago and is now managed by the Queensland Government.

At Mary Kathleen, the run-of-mine ore grade of $0.13 \% \mathrm{U}$ was upgraded via radiometric ore sorting to $0.2 \% \mathrm{U}$ before processing. The radiometric sorting comprised measurement of the radioactivity of $10 \%$ of each haul truck's load, with the result determining if the truckload of ore went to high-grade, lowgrade or waste piles. ${ }^{13,15}$ Extraction of the REE was actively suppressed during leaching in the first phase of production (1958-1963), as dissolution of the REE-hosting allanite consumed acid and yielded solutions containing high concentrations of dissolved $\mathrm{Si}$ and La. ${ }^{21}$

The Mary Kathleen U process, as operated between 1976 and 1982, is described and summarized in Fig. 1. The process was modified from the first stage of operation. Pre-leaching processing comprised three-stage crushing of the ore to c. 1/ 2 in. (c. $1.27 \mathrm{~mm}$ ) size before grinding by utilizing a rod mill and two ball mills with cyclone classifiers to reduce the feed to $65 \%$ passing 200 mesh, or approximately $74 \mu \mathrm{m}$; throughput was increased by addition of a third ball mill. ${ }^{21}$ The $U$ was then leached from the ground ore using sulfuric acid in continuously stirred tank reactors in series, 5 tanks, 6-8 h residence time. The process acid utilization was $72 \mathrm{~kg} \mathrm{H}_{2} \mathrm{SO}_{4} / \mathrm{t}$-ore (including $\mathrm{SX}$ ), $\mathrm{MnO}_{2}$ was added to increase the oxidation-reduction potential. $^{22}$ Solid-liquid separation and tailings washing was achieved by 5 -stage counter-current decantation. The tailings solids contained about 3\% total REE content. The $U$ was recovered from the 
pregnant leach solution using SX (4-stage load, 4stage strip), which replaced ion exchange resin columns from the original process plant. ${ }^{15} \mathrm{U}$ product was recovered from the solvent extraction eluate by ammonia precipitation (2 stage) which replaced magnesia precipitation. The precipitate was washed over 2 stages, centrifuged, and calcined to obtain $\mathrm{U}_{3} \mathrm{O}_{8}$. Changes in extraction methods were likely a key reason for the REE concentration zonation observed in the tailings dam,${ }^{23}$ with higher REE concentrations at depth representing the process tailings from the first phase of mineral processing. ${ }^{24}$

Tailings were deposited in a 130-ha tailings storage facility (TSF) ca. $2 \mathrm{~km}$ north of the open pit, with an estimated tailings mass of 5.57.5 Mt. ${ }^{12,13}$ The LREO grade has been reported to range between 2 and $4.5 \%{ }^{23}$ The processed tailings were pumped to the tailings dam which was constructed using metasedimentary waste rock. The liquor from the tailings is collected in the evaporation pond located immediately below the tailings dam. The area location and cross-section of the TSF have been described previously. ${ }^{23}$ Figures 2 and 3 are recent photographs of the Mary Kathleen open pit and natural weathering of the tailings dam consistent with bioleaching, respectively. Upon the cessation of mining in 1982 , the township site, the mill, and other surface plant were dismantled and removed. The treatment plant was decontaminated using pressurised water jets, washing with acid solution, and scrubbing and sandblasting. The product dryer, solvent extraction tanks, thickeners, and other equipment and pipework were demolished and buried in the tailings dam. Contaminated surface soils were also trucked to the tailings dam for burial. The tailings facility was then covered with a 1-m-thick layer of waste rock. ${ }^{13}$ Water monitoring continues, at and around the project site, by the Queensland Department of Natural Resources, Mining and Energy.

The tailings comprise of primary gangue minerals such as quartz, andradite-grossular, albite, allanite, epidote, diopside, actinolite, scapolite, and chlorite, and secondary phases, gypsum and jarosite. ${ }^{13,25}$ Other minerals detected include magnetite, muscovite, anatase, rutile, hematite, and siderite. ${ }^{26}$ The major elements (> 1 wt.\%) include $\mathrm{Ca}$ and $\mathrm{Fe}$, and minor elements (> $1000 \mathrm{ppm}$ ) include $\mathrm{Ce}, \mathrm{La}, \mathrm{K}$, $\mathrm{Mg}, \mathrm{Mn}, \mathrm{Na}, \mathrm{P}$, and $\mathrm{S} .{ }^{25}$ The tailings also contain $\mathrm{As}, \mathrm{Ba}, \mathrm{Cu}, \mathrm{Pb}, \mathrm{Th}$, and $\mathrm{V}$ with concentrations $>100 \mathrm{ppm}$, and trace elements $\mathrm{Ni}, \mathrm{Sr}, \mathrm{U}, \mathrm{Y}$, and $\mathrm{Zn}$.

Similar to the original ore, the tailings are also strongly enriched in LREO, with an average grade of $2.3 \%$. Of the LREOs, La and Ce were found to have the highest concentrations, averaging $0.75 \%$ $\mathrm{La}_{2} \mathrm{O}_{3}$ and $1.25 \% \mathrm{CeO}_{2}{ }^{23}$ Also present are trace amounts of praseodymium and neodymium. ${ }^{26}$ The REE are largely hosted by allanite, which is mostly associated with garnet, amphibole, and Ca-sulfate. $^{23}$ Stillwellite was also detected as the next REE-bearing mineral, as well as trace amounts of bastnaesite, parasite, and coskrenite. Uranium and thorium were noted to have an average grade of $0.01 \% \mathrm{U}_{3} \mathrm{O}_{8}$ and $0.02 \% \mathrm{ThO}_{2}$, indicating the material is radioactive, a common feature of REEbearing tailings. ${ }^{27}$

Based on REE and U concentrations, two zones exist (1) an upper zone (0-15 m depth) with lower concentrations (0.45-3\% LREO), and (2) a lower zone (> $15 \mathrm{~m}$ depth) with higher concentrations

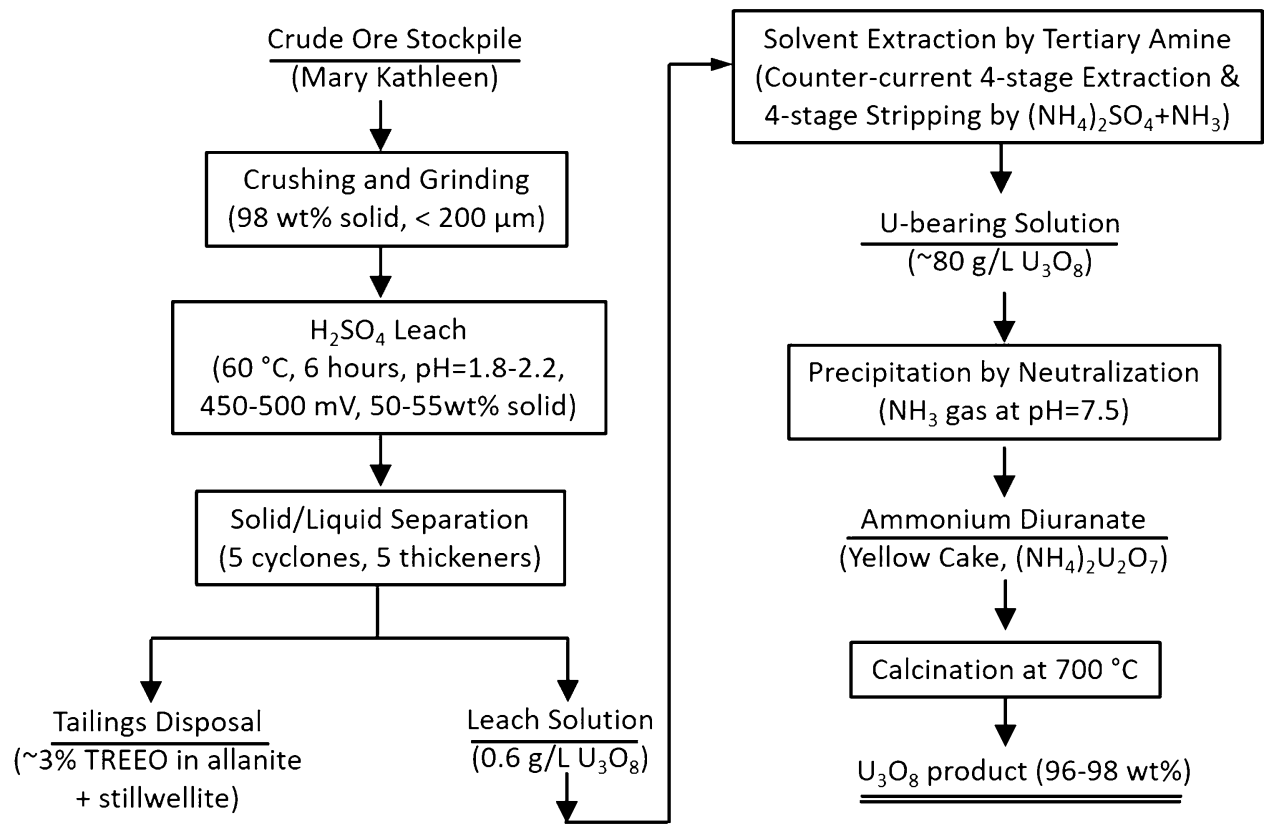

Fig. 1. Flowsheet of uranium extraction of Mary Kathleen Uranium Ltd based on description in Ref. 24 


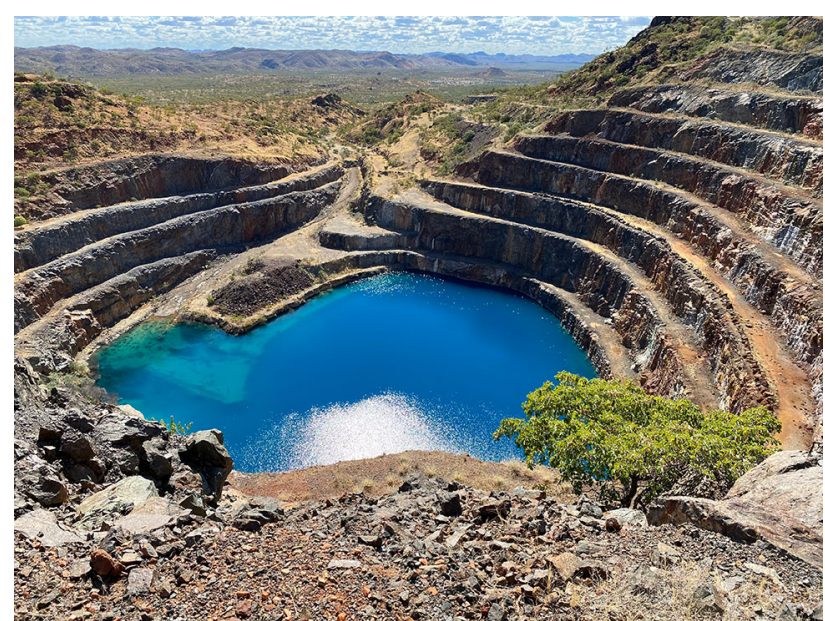

Fig. 2. Mary Kathleen open pit

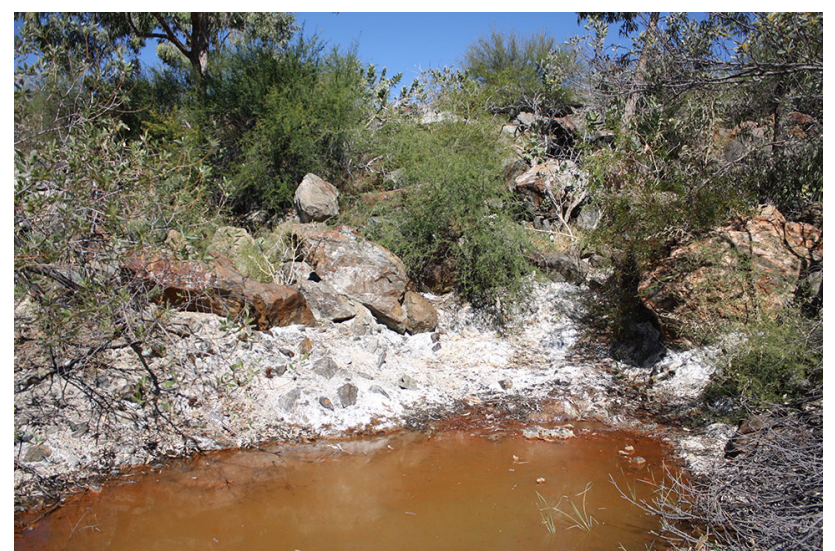

Fig. 3. Mary Kathleen tailings dam exhibiting natural weathering

( $>3-4.58 \%$ LREO). A gradual increase in $\mathrm{S}$ and associated chalcophile elements from the bottom to the top of the TSF has also been reported. These can be attributed to the change in ore type between the two phases of operation at the mine. A change in the processing between the two phases of operation has also affected the particle size distribution. The lower zone exhibits a finer size distribution, mostly in the $125-\mu \mathrm{m}$ particle size fraction. ${ }^{23}$

\section{CONVENTIONAL REE PROCESS TECHNOLOGIES}

Beneficiation of REE minerals includes a combination of gravity concentration, magnetic separation, electrostatic separation, and froth flotation. Beneficiation allows the REE minerals from the ore to be enriched by means of physical separations. Beneficiation can enrich the valuable REE associated with minerals, such as bastnasite (carbonatefluoride), monazite (phosphate) and xenotime (yttrium-phosphate) into REE concentrates which are then suitable for hydrometallurgical treatment to further separate and concentrate the REE. ${ }^{28}$ For example, monazite can be physically concentrated by density separations owing to its high specific gravity and xenotime can be separated from other minerals with magnetic separation techniques. ${ }^{29}$ Mineral surface properties can be used for separations by froth flotation which is applied to recover bastnasite. Flotation is also the preferred beneficiation technique for fine-grained ores and for complex ores, such as those from Mount Weld. A desliming stage is carried out prior to flotation to remove the fine particles, finer than $10 \mu \mathrm{m} .{ }^{30}$

With the exception of RE ion-adsorbed clay minerals, most of the REE cannot be fully dissolved into aqueous solution (e.g., water, acid, or alkaline) at ambient temperature due to their mineral associations, which render them inaccessible to leaching solutions or stable in the solid phase. To unlock the REE in the concentrates, a primary leaching stage using intense processing conditions can increase their extraction from REE-containing minerals. ${ }^{31}$ As shown in Table I, there are several primary leach methods to extract the REE minerals, which can be categorized into four main groups: alkaline, acid, chlorination, and ion exchange. In each group, the primary leach conditions often include a roasting pre-treatment along with a subsequent leach. The key advantages (+) and disadvantages (-) of each method are summarised in Table I.

For the acid method, sulfuric acid $\left(\mathrm{H}_{2} \mathrm{SO}_{4}\right)$, hydrochloric acid $(\mathrm{HCl})$, nitric acid $\left(\mathrm{HNO}_{3}\right)$, and hydrofluoric acid (HF) can be employed for different types of REE concentrates. For the alkaline method, sodium hydroxide $(\mathrm{NaOH})$ and sodium carbonate $\left(\mathrm{Na}_{2} \mathrm{CO}_{3}\right)$ are commonly used. Oxidation-roasting and salt-roasting are intensification steps which enhance the subsequent acid and alkaline leaching. In the chlorination method, chlorine gas $\left(\mathrm{Cl}_{2}\right)$ and charcoal are used to decompose REE concentrates at high temperature. The ion exchange method can only be effectively used to extract REE from ionadsorption clay deposits using $\mathrm{NaCl}$ or $\left(\mathrm{NH}_{4}\right)_{2} \mathrm{SO}_{4}$ electrolyte solutions. In the following sections, these four processing approaches are discussed in detail.

\section{Alkaline Leach Treatment}

The alkaline treatment method includes caustic soda $(\mathrm{NaOH})$ digestion as well as sodium carbonate roasting with a subsequent water-leach, which are suitable for monazite and xenotime containing phosphate-type minerals. ${ }^{32}$ The main advantages of these methods are that they are well-established processes with minimal corrosion problems, allowing for low-cost materials of construction to be used and a saleable by-product (sodium phosphate as fertilizer) is generated which offsets the cost of reagents. The drawbacks are the requirement of the high grade of REE concentrates (REOs $>60 \%$ ) with small particle size $(<43 \mu \mathrm{m})$.

Figure 4 shows the caustic soda leach process flowsheet for monazite and xenotime feed. The digestion is carried out at $140-150^{\circ} \mathrm{C}$ in autoclaves 
Table I. Primary leach methods to liberate and extract rare earth elements from various mineral types with key advantages (+) and disadvantages (-) noted

\begin{tabular}{|c|c|c|c|c|}
\hline \multirow[b]{2}{*}{$\begin{array}{l}\text { Primary } \\
\text { leach type }\end{array}$} & \multicolumn{2}{|c|}{ Primary leach conditions } & \multirow[b]{2}{*}{ REE mineral types } & \multirow[b]{2}{*}{ Remarks } \\
\hline & $\begin{array}{l}\text { Roasting } \\
\text { conditions }\end{array}$ & $\begin{array}{l}\text { Leach } \\
\text { conditions }\end{array}$ & & \\
\hline \multirow[t]{2}{*}{ Alkaline } & $\mathrm{n} / \mathrm{a}$ & $\begin{array}{l}\mathrm{NaOH}, 140- \\
150^{\circ} \mathrm{C} \text { (auto- } \\
\quad \text { clave) }\end{array}$ & $\begin{array}{l}\text { Monazite }^{76,77} \text {; Bastnaesite } \\
\text { mixed monazite and bastnae- } \\
\text { site }{ }^{79} ; \text { Xenotime }\end{array}$ & $\begin{array}{c}\text { (+): (1) Phosphate recycling; (2) } \\
\text { easy fluorite separation } \\
\text { (-): (1) Requirement of low } \\
\text { reactive silicates and iron } \\
\text { contents in RE concentrate }\end{array}$ \\
\hline & $\begin{array}{l}\mathrm{Na}_{2} \mathrm{CO}_{3}, \quad 800- \\
900^{\circ} \mathrm{C}\end{array}$ & $\begin{array}{c}\mathrm{H}_{2} \mathrm{SO}_{4}(20 \%) \\
80-90^{\circ} \mathrm{C} ; \text { alter- } \\
\text { natively, HCl } \\
(15-20 \%), 80- \\
90^{\circ} \mathrm{C}\end{array}$ & $\begin{array}{l}\text { Monazite }{ }^{81-83} \text {; mixed monazite } \\
\text { and bastnaesite } \\
84,85\end{array}$ & $\begin{array}{c}\text { (+): (1) Phosphate recycling; }(2) \\
\text { easy fluorite separation } \\
(-):(1) \text { Requirement of low } \\
\text { reactive silicates and iron } \\
\text { contents in RE concentrate; }(2) \\
\text { scale formation in rotary kiln } \\
\text { during roasting }\end{array}$ \\
\hline \multirow[t]{7}{*}{ Acid } & $\begin{array}{l}\mathrm{H}_{2} \mathrm{SO}_{4}(>93 \%) \\
250-300^{\circ} \mathrm{C}(\text { acid } \\
\text { bake })\end{array}$ & Water, $30-40^{\circ} \mathrm{C}$ & $\begin{array}{c}\text { Monazite }^{33,86} \text {; Bastnaesite } \\
\text { Mixed monazite and } \\
\text { bastnaesite } \\
\text { boparite }^{90,93} \text {; Xenotime } \text { Allanite }^{94,95} ; \\
\text { Ludialyte }^{96,97} \text {; Pyrochlore } \\
\text { Euxenite and davidite }^{99}\end{array}$ & $\begin{array}{c}\text { (+): (1) A robust and mature } \\
\text { process for various concentrate; } \\
\text { (2) } 90 \% \text { of mixed concentrates use } \\
\text { this method; (3) High RE extrac- } \\
\text { tions }(>95 \%) \\
\text { (-): (1) Relatively high } \\
\text { impurity dissolution (e.g., U, } \\
\text { Th, Fe, Si, Al); (2) large amount } \\
\text { of acidic wastewater }\end{array}$ \\
\hline & $\begin{array}{l}\mathrm{H}_{2} \mathrm{SO}_{4}(>93 \%) \\
300-800^{\circ} \mathrm{C} \text { (acid } \\
\text { bake) }\end{array}$ & $\begin{array}{c}\mathrm{H}_{2} \mathrm{SO}_{4}(\sim 10 \%) \\
20-25^{\circ} \mathrm{C}\end{array}$ & Monazite $^{34} ;$ Allanite $^{100}$ & $\begin{array}{l}\text { (+): (1) Suitable for } \mathrm{RE} \text { concen- } \\
\text { trates with high-impurity levels; } \\
\text { (2) better impurity rejection (Fe, } \\
\text { Th }<10 \%) \\
\text { (-): (1) Relatively low } \mathrm{RE} \\
\text { extraction rate }(70-90 \%) ;(2) \\
\text { emitting } \mathrm{SO}_{2} \text { gas; (3) large } \\
\text { amount of acidic wastewater }\end{array}$ \\
\hline & $\begin{array}{l}400-680^{\circ} \mathrm{C}(\text { oxi- } \\
\text { dation roast) }\end{array}$ & $\begin{array}{l}\mathrm{H}_{2} \mathrm{SO}_{4}(20 \%) \\
\quad 85-95^{\circ} \mathrm{C}\end{array}$ & Bastnaesite $^{101,102}$ & $\begin{array}{l}\text { (+): Suitable for bastnaesite con- } \\
\text { centrates }\end{array}$ \\
\hline & $\begin{array}{l}400-680^{\circ} \mathrm{C} \text { (oxi- } \\
\text { dation roast) }\end{array}$ & $\begin{array}{l}\mathrm{HCl}(30 \%), 55- \\
95^{\circ} \mathrm{C}\end{array}$ & Bastnaesite $^{87,103}$ & $\begin{array}{l}\text { (-) Emitting fluorine gas } \\
(+) \text { : (1) Fast leach kinetics; (2) } \\
\text { higher RE solubilities }\end{array}$ \\
\hline & $\mathrm{n} / \mathrm{a}$ & $\mathrm{HCl}(30 \%), 95^{\circ} \mathrm{C}$ & Bastnaesite $^{104} ;$ Eudialyte $^{105}$ & $\begin{array}{c}\text { (-): (1) } \mathrm{HCl} \text { vapor challenges; } \\
\text { (2) corrosion problems }\end{array}$ \\
\hline & $\mathrm{n} / \mathrm{a}$ & $\begin{array}{c}\mathrm{HNO}_{3}(50-60 \%) \\
60^{\circ} \mathrm{C}\end{array}$ & Apatite $^{92} ;$ Eudialyte $^{92}$ & $\begin{array}{l}\text { (+): (1) Fast leach kinetics; }(2) \\
\text { higher RE solubilities } \\
\text { (-): (1) Expensive leach } \\
\text { reagents; (2) emitting } \mathrm{NO}_{x} \text { gas }\end{array}$ \\
\hline & $\mathrm{n} / \mathrm{a}$ & $\mathrm{HF}(50 \%), 100^{\circ} \mathrm{C}$ & Fergusonite $^{106}$ & $\begin{array}{c}\text { (+): Required for Nb-bearing } \\
\text { minerals } \\
(-): \text { (1) Emitting HF gas; }(2) \\
\text { corrosion problems }\end{array}$ \\
\hline Chlorination & $\begin{array}{l}\text { Carbon, } \mathrm{Cl}_{2} \text { gas, } \\
\quad 950-1100^{\circ} \mathrm{C}\end{array}$ & $\mathrm{n} / \mathrm{a}$ & $\begin{array}{l}\text { Bastnasite, monazite, allanite, } \\
\text { cerite, xenotime, euxenite, fergu- } \\
\text { sonite, gadolinite }\end{array}$ & $\begin{array}{c}\text { (+): Direct preparation of RE } \\
\text { chlorides } \\
(-) \text { : (1) High energy } \\
\text { consumption; (2) corrosion } \\
\text { problems }\end{array}$ \\
\hline $\begin{array}{l}\text { Ion } \\
\text { change }\end{array}$ & $\mathrm{n} / \mathrm{a}$ & $\begin{array}{c}\sim 7 \% \mathrm{NaCl} \text { or } \\
1-2 \% \\
\left(\mathrm{NH}_{4}\right)_{2} \mathrm{SO}_{4} \text { solu- } \\
\text { tion; } \mathrm{pH}=4\end{array}$ & $\begin{array}{l}\text { REE-adsorbed aluminosili- } \\
\text { cate }^{37,107}\end{array}$ & $\begin{array}{l}(-) \text { : Only suitable for ion-ad- } \\
\text { sorbed clay minerals }\end{array}$ \\
\hline
\end{tabular}


with $3-4 \mathrm{~h}$ of residence time. The main reactions in the autoclave are summarized in Eqs. 1-3. The obtained digestion solution containing sodium phosphate and sodium hydroxide is sent to evaporative crystallization for sodium phosphate by-product recovery. After crystallisation, the spent digestion liquor concentrated in sodium hydroxide is recycled back to the caustic digestion stage.

$$
\begin{gathered}
\mathrm{REPO}_{4}+3 \mathrm{NaOH}=\mathrm{RE}(\mathrm{OH})_{3} \downarrow+\mathrm{Na}_{3} \mathrm{PO}_{4} \\
\mathrm{Th}_{3}\left(\mathrm{PO}_{4}\right)_{4}+12 \mathrm{NaOH}=3 \mathrm{Th}(\mathrm{OH})_{4} \downarrow+4 \mathrm{Na}_{3} \mathrm{PO}_{4} \\
2 \mathrm{U}_{3} \mathrm{O}_{8}+\mathrm{O}_{2}+6 \mathrm{NaOH}=3 \mathrm{Na}_{2} \mathrm{U}_{2} \mathrm{O}_{7} \downarrow+3 \mathrm{H}_{2} \mathrm{O}
\end{gathered}
$$

The digestion residue is a mixture of various hydroxides, including $\mathrm{RE}, \mathrm{U}, \mathrm{Th}$, and $\mathrm{Fe}$. The washed mixture of hydroxides with low $\mathrm{P}_{2} \mathrm{O}_{5}$ content $(<1$ wt.\%) are preferentially dissolved by $\mathrm{HCl}$ at an equilibrium $\mathrm{pH}$ of about 3 . After that, the REE and radioactive radium are dissolved into the $\mathrm{HCl}$ leach solution, whereas the most of $\mathrm{U}, \mathrm{Th}, \mathrm{Fe}$, and small amount of REE ( $<10 \mathrm{wt} . \%)$ remain in the solid leach residue. This residue can be leached further with $\mathrm{HNO}_{3}$, followed by multi-stage solvent extraction (tributyl phosphate, TBP) for separating $\mathrm{U}$ and $\mathrm{Th}$ from the REE. Radioactive $\mathrm{RaCl}_{2}$ $\left(10^{-10} \mathrm{~mol} / \mathrm{L}\right)$ in the leach solution is removed through co-precipitation of $\mathrm{BaSO}_{4}$ and $\mathrm{RaSO}_{4}$ by adding $\mathrm{H}_{2} \mathrm{SO}_{4}$ and $\mathrm{BaCl}_{2}$. The trace $\mathrm{RaSO}_{4}$ is taken into the structure of the relatively large amount of $\mathrm{BaSO}_{4}$ precipitate through isomorphic substitution. The purified mixed $\mathrm{RECl}_{3}$ can be used as the feed material for further processing stages to separate and recover the individual REE.

\section{Acid Leach Treatment}

Among the many acid leach processes in Table I, $\mathrm{H}_{2} \mathrm{SO}_{4}$ baking is a common approach for converting the REE minerals to REE sulfate phases at elevated temperatures $\left(250-300^{\circ} \mathrm{C}\right)$, after which the sulfate salts can be readily dissolved in a water leach stage. ${ }^{33}$ Other mineral acids, such as hydrochloric acid, hydrofluoric acid, and nitric acid, are not suitable for acid baking as they are lost to the gas phase due to their relatively low boiling points. The other acids are more suitable for minor REE minerals, such as eudialyte, apatite, and fergusonite in Table I. Hydrochloric acid and nitric acid can also be widely used in the preferential leaching of REE hydroxides and REE double-sulfate precipitates in subsequent stages. Acid leaching is a robust method for various grades of REE concentrates. The disadvantages of these methods include equipment corrosion problems and the management of the high concentrations of other impurities in the leach solutions. ${ }^{34}$

Figure 5 shows the $\mathrm{H}_{2} \mathrm{SO}_{4}$ roasting leach flowsheet of monazite, xenotime, and bastnaesite. In the flowsheet, the dosage of concentrated $\mathrm{H}_{2} \mathrm{SO}_{4}$ (> 93 wt.\%) is around 1.7-2.0 times the RE concentrates mass. ${ }^{35}$ The roasting temperature for the mixture of REE concentrates and concentrated $\mathrm{H}_{2} \mathrm{SO}_{4}$ is at $250-300^{\circ} \mathrm{C}$ for $1-3 \mathrm{~h}$. REE concentrates react with $\mathrm{H}_{2} \mathrm{SO}_{4}$ and decompose to REE sulfates, $\mathrm{U}$ and Th sulfates, $\mathrm{HF}$, and $\mathrm{CO}_{2}$ gases from the bastnaesite. The typical reactions are shown in Eqs. 4-7:

$$
\begin{gathered}
2 \mathrm{REPO}_{4}+3 \mathrm{H}_{2} \mathrm{SO}_{4}=\mathrm{RE}_{2}\left(\mathrm{SO}_{4}\right)_{3}+2 \mathrm{H}_{3} \mathrm{PO}_{4} \\
2 \mathrm{REFCO}_{3}+3 \mathrm{H}_{2} \mathrm{SO}_{4}=\underset{\uparrow}{\uparrow}+2 \mathrm{RE}_{2}\left(\mathrm{SO}_{4}\right)_{3}+2 \mathrm{HF} \uparrow+2 \mathrm{CO}_{2} \\
\mathrm{Th}_{3}\left(\mathrm{PO}_{4}\right)_{4}+6 \mathrm{H}_{2} \mathrm{SO}_{4}=3 \mathrm{Th}\left(\mathrm{SO}_{4}\right)_{2}+4 \mathrm{H}_{3} \mathrm{PO}_{4} \\
2 \mathrm{U}_{3} \mathrm{O}_{8}+\mathrm{O}_{2}+6 \mathrm{H}_{2} \mathrm{SO}_{4}=6 \mathrm{UO}_{2} \mathrm{SO}_{4}+6 \mathrm{H}_{2} \mathrm{O}
\end{gathered}
$$

After roasting, the decomposed concentrates are cooled and then mixed with water at $30-40^{\circ} \mathrm{C}$ for $2-3 \mathrm{~h}$. The concentrate must be sufficiently cooled since the solubilities of RE sulfates decrease with the increasing of temperature in the leach. The water usage is around 7-8 times the mass of the decomposed concentrates. In the leach solution, total REE concentration is controlled at approximately $60 \mathrm{~g} / \mathrm{L}$. Then, $\mathrm{Na}_{2} \mathrm{SO}_{4}$ salts are added into the leach solution to separate the REE by forming double-salt precipitates $\left(x \mathrm{RE}_{2}\left(\mathrm{SO}_{4}\right)_{3} \cdot y \mathrm{Na}_{2} \mathrm{SO}_{4} \cdot z \mathrm{H}_{2} \mathrm{O}\right)$. Meanwhile, around $50-60 \%$ of the $\mathrm{Th}$ is precipitated as a double salt $\left(\mathrm{Th}\left(\mathrm{SO}_{4}\right)_{2} \cdot \mathrm{Na}_{2} \mathrm{SO}_{4}\right)$. After double-salt precipitation, there are still 1-2 wt.\% of total REE ions, mainly heavy REE ions, left in the filtrate. These heavy REE ions can be recovered as insoluble REE oxalates by adding oxalic acid $\left(\mathrm{H}_{2} \mathrm{C}_{2} \mathrm{O}_{8}\right)$ into the solution. The mixed double-salt precipitates are treated with $\mathrm{NaOH}$ solution to convert them into $\mathrm{REE}$ hydroxides at $95^{\circ} \mathrm{C}$ for $4-6 \mathrm{~h}$. After washing the hydroxide mixtures with hot water, the REEare preferentially dissolved into the $\mathrm{HCl}$ leach solution at equilibrium $\mathrm{pH}=3-4$, while $\mathrm{Th}$ and $\mathrm{Fe}$ hydroxide remain in the residue. The mixed REE chloride solution is sent to SX for separation of light, middle, and heavy REE intermediate products. Di(2-ethylhexyl)phosphoric acid (D2EHPA) is one of the most important extractants for REE separation from different mineral acid solutions. The extraction ability of D2EHPA for individual REE ions increases with the decrease of the ionic radii of the ions. Based on the La contraction, the radii of the trivalent $R E E$ ions reduces as a function of increasing atomic number from $\mathrm{La}^{3+}$ to $\mathrm{Lu}^{3+}$. The solvent extraction section consists of 10 extraction and 16 scrubbing stages. Heavy RE ions ( $\mathrm{Tb}$, Dy, holmium, Er, terbium, ytterbium, and lutetium) with small ionic radii are 
Toward Closing a Loophole: Recovering Rare Earth Elements from Uranium Metallurgical Process Tailings

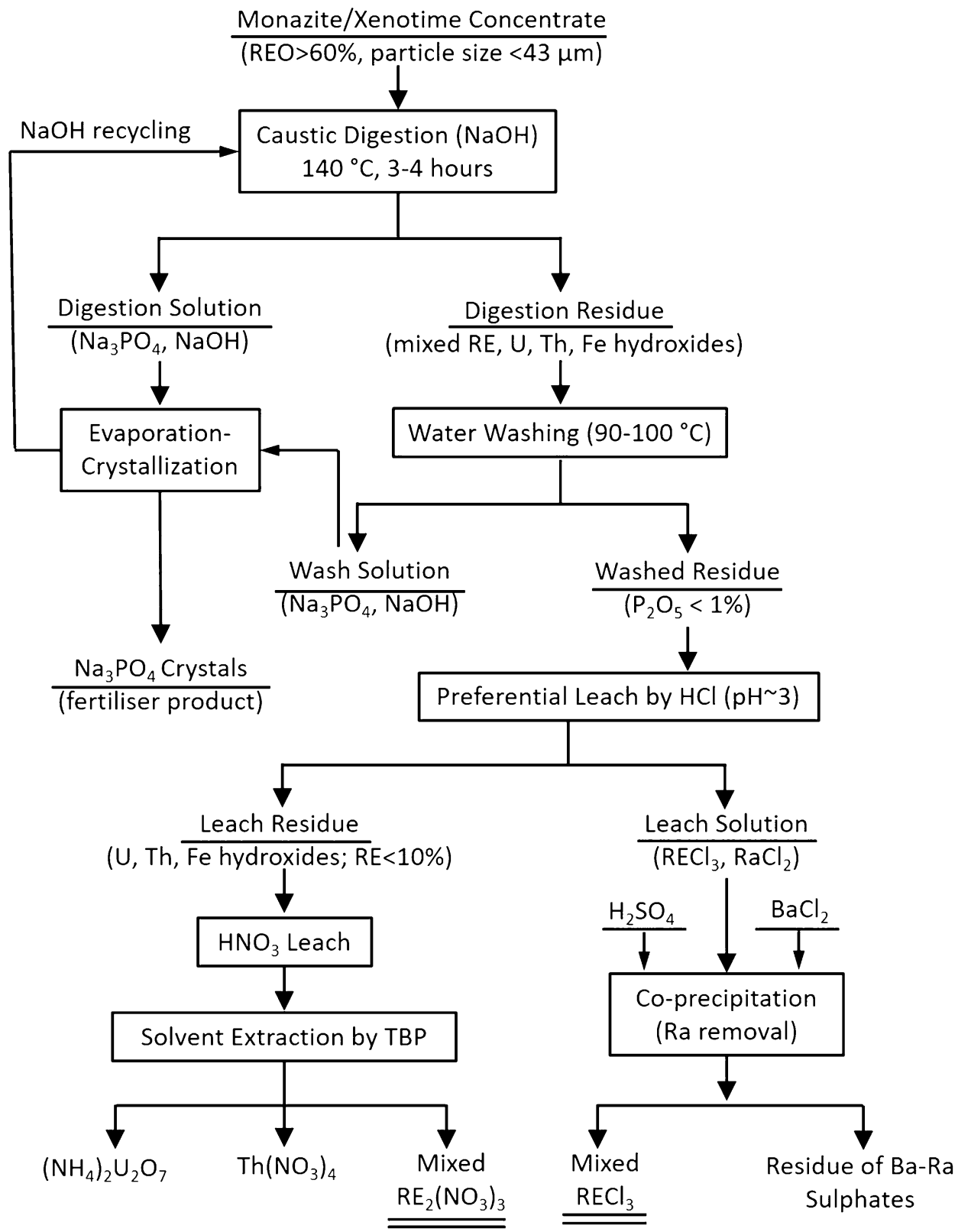

Fig. 4. Alkaline leach flowsheet of RE-bearing concentrates (monazite, xenotime)

preferentially extracted by D2EHPA, followed by middle RE ions (samarium, Eu, and Gd). The light $\mathrm{RE}$ ions ( $\mathrm{La}, \mathrm{Ce}, \mathrm{Pr}$, and $\mathrm{Nd}$ ) remain in the raffinate after extraction at an equilibrium $\mathrm{pH}$ of $4-5$. Then, the REE-loaded organic phase proceeds to a selective stripping section. Two $\mathrm{mol} / \mathrm{L} \mathrm{HCl}$ is used to strip the middle REE ions from the organic phase (> 10 stripping stages), followed by 6 $7 \mathrm{~mol} / \mathrm{L} \mathrm{HCl}$ to strip heavy REE ions into another aqueous phase ( $>10$ stripping stages). After that, the barren organic phase is washed and sent back to the next extraction cycle. Finally, the intermediate REE products from solvent extraction section are the light, middle, and heavy REE chlorides.

\section{Chlorination Treatment}

Chlorination treatment is a high-temperature method for directly producing anhydrous REE chlorides from REE concentrates. ${ }^{36}$ REE concentrates mixed with charcoal are pressed into briquettes, baked at $120-140^{\circ} \mathrm{C}$ and then chlorinated in a graphite reactor at $950-1100^{\circ} \mathrm{C}$. During the process, chloride compounds with low boiling points, such as $\mathrm{ThCl}_{4}, \mathrm{UCl}_{4}, \mathrm{FeCl}_{3}$, and $\mathrm{SiCl}_{4}$, are evaporated and removed from the off-gas. Chloride compounds with high boiling points, including REE chlorides, $\mathrm{CaCl}_{2}$ and $\mathrm{MgCl}_{2}$, are melted into a fusion state for further leach treatment. There are significant technical disadvantages for this high-temperature chlorination process including severe corrosion of 

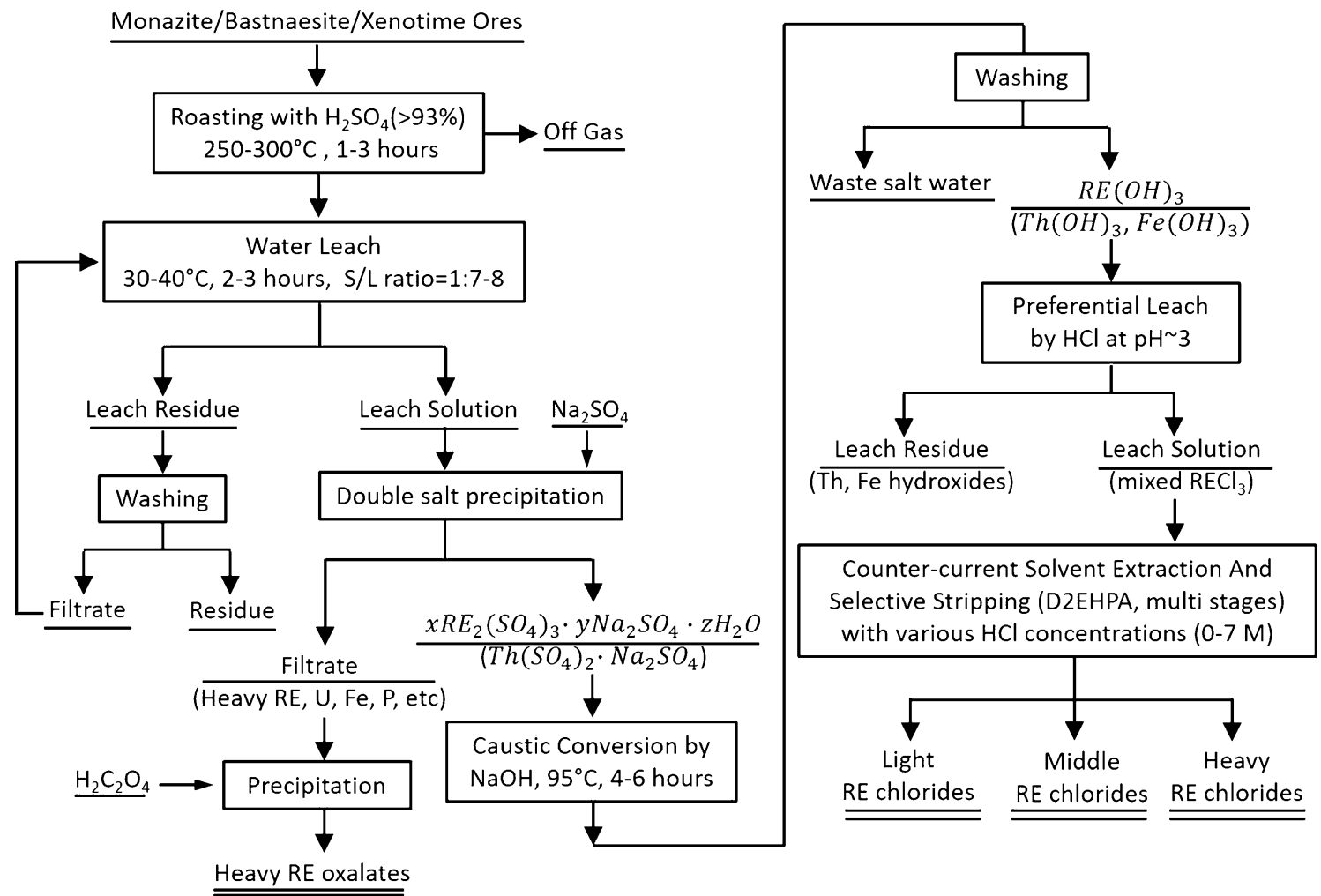

Fig. 5. Sulfuric acid roasting flowsheet of RE-bearing concentrates (monazite, xenotime and bastnaesite)

equipment, Th contamination in REE chlorides, the complex composition of the REE-bearing fusion salts and overall harsh operation conditions. The typical reactions for REE minerals are shown in Eqs. 8-11:

$$
\begin{aligned}
2 \mathrm{REPO}_{4(\mathrm{~s})}+3 \mathrm{C}_{(\mathrm{s})}+ & 6 \mathrm{Cl}_{2(\mathrm{~g})} \\
= & 2 \mathrm{RECl}_{2(\mathrm{~s}, \mathrm{l})}+2 \mathrm{POCl}_{3(\mathrm{~g})}+3 \mathrm{CO}_{2(\mathrm{~g})} \\
\mathrm{REFCO}_{3(\mathrm{~s})}=\mathrm{REOF}_{(\mathrm{s})}+\mathrm{CO}_{2(\mathrm{~g})} & \\
6 \mathrm{REOF}_{(\mathrm{s})}+3 \mathrm{C}_{(\mathrm{s})}+6 \mathrm{Cl}_{2(\mathrm{~g})}= & 4 \mathrm{RECl}_{2(\mathrm{~s}, \mathrm{l})}+2 \mathrm{REF}_{3(\mathrm{~s})} \\
& +3 \mathrm{CO}_{2(\mathrm{~g})}
\end{aligned}
$$

$\mathrm{REOF}_{(\mathrm{s})}+\mathrm{C}_{(\mathrm{s})}+2 \mathrm{Cl}_{2(\mathrm{~g})}=\mathrm{RECl}_{2(\mathrm{~s}, \mathrm{l})}+\mathrm{ClF}_{(\mathrm{s})}+\mathrm{CO}_{(\mathrm{g})}$

\section{Ion-Exchange Leach Treatment}

Weathered elution-deposited REE ore is a type of clay minerals where REE (0.05-0.3 wt.\%) are physically adsorbed onto the aluminosilicate structures. ${ }^{37}$ Thus, an ion-exchange leach treatment is an efficient way to extract REE ions from the clay minerals without needing to dissolve the host mineral. This is achieved using an electrolyte solution such as $\mathrm{NaCl},\left(\mathrm{NH}_{4}\right)_{2} \mathrm{SO}_{4}$, which elutes the REE ions from clay minerals based on the cation exchange reaction mechanism. The typical reaction for REE minerals is shown in Eq. 12. It is notable that the leaching efficiency of electrolyte ions for REE extraction is inversely proportional to the ion hydration energy, following the order $\mathrm{Cs}^{+}>\mathrm{NH}_{4}^{+}>\mathrm{K}^{+}>\mathrm{Na}^{+}>\mathrm{Li}^{+}$.

$$
\begin{aligned}
& \left(\mathrm{Al}_{2} \mathrm{Si}_{2} \mathrm{O}_{5}(\mathrm{OH})_{4}\right)_{\mathrm{m}} \cdot n\left(\mathrm{RE}^{3+}\right)_{(\mathrm{s})}+3 n \mathrm{NH}_{4(\mathrm{aq})}^{+} \\
& \quad=\left(\mathrm{Al}_{2} \mathrm{Si}_{2} \mathrm{O}_{5}(\mathrm{OH})_{4}\right)_{\mathrm{m}} \cdot 3 \mathrm{n}\left(\mathrm{NH}_{4}^{+}\right)_{(\mathrm{s})}+n \mathrm{RE}_{(\mathrm{aq})}^{3+}
\end{aligned}
$$

\section{Separation of Rare Earth Elements}

After extracting REE during the leach processes, the obtained mixed REE salts must be further processed to separate the elements into high-purity individual $\mathrm{RE}$ salt products suitable for industrial applications. The processes for separating individual REs from naturally occurring REE mixtures is largely based on the subtle differences in electronic structures and ionic radii owing to the lanthanide contraction phenomenon, which is one of the most challenging separations in the field of hydrometallurgy. To achieve this goal, there are many different methods including fractional crystallization and precipitation, ion exchange, and solvent extraction. ${ }^{38}$ A comparison of different methods is shown in Table II. In particular, multi-stage solvent 
extraction offers a more robust and efficient way for the production of individual REs with high purities at industrial scales. ${ }^{39,40}$

\section{ALTERNATIVE REE PROCESS TECHNOLOGIES}

\section{Phyto-Extraction}

Phyto-extraction involves the use of selected hyperaccumulator plants (i.e., plants that have an ability to accumulate extremely high concentrations of certain metals in their shoots) to extract high-value metals from unconventional resources, including low-grade metal soils and mining waste material. ${ }^{41-43}$ In this approach, selected hyperaccumulator plants ('metal crops') with desirable traits are grown over (spatially large) sub-economic ore bodies, mining wastes, or metal-contaminated soils followed by harvesting and postharvest processing of the biomass to produce a commercial high-grade bio-ore. ${ }^{43}$ For effective phyto-extraction, selected hyperaccumulator plants must have high biomass production and high shoot metal concentrations. Technical difficulties in economic recovery of metals from lowgrade ores and high metal prices have contributed to an increased effort in developing phyto-extraction. ${ }^{44}$ Compared to strip-mining operations, phyto-extraction has an environmental impact like agriculture or agroforestry, and it does not require mine site rehabilitation at the end of life. ${ }^{45}$ Phytoextraction is expected to be transformative in the extraction of those elements not accessible by traditional mining technologies, with an added advantage of in situ rehabilitation. ${ }^{43}$ The key steps in developing a sustainable phyto-mining operation include: (1) identification of potential locations, (2) screening for suitable hyperaccumulator plants, (3) selection of potential metal crops, (4) testing the agronomy of metal crops, and (5) evaluation of possible metal recovery methods. ${ }^{46,47}$
REE hyperaccumulation is defined when plants have in excess of $1000 \mu \mathrm{g} \mathrm{g}^{-1}$ dry weight total REE in their shoots, and there are currently 22 plant species known globally to be REE hyperaccumulators. ${ }^{48}$ REE hyperaccumulation appears to be an erratic phenomenon. It is hypothesized that REE uptake is a consequence of existing mechanisms for uptake of $\mathrm{Al}^{3+}, \mathrm{Si}^{3+}$, and/or $\mathrm{Mn}^{3+}$, and plants that hyperaccumulate these elements have potential for REE hyperaccumulation. The fern Dicranopteris linearis is a well-known REE metal crop that is being actively explored for REE phyto-extraction in China (Fig. 6) ${ }^{48}$ The physiological mechanisms for enhanced uptake and accumulation of REE are, however, still largely unknown. Recent investigations on $D$. linearis have revealed that REE ( $\mathrm{La}+$ $\mathrm{Ce}$ ) are primarily colocalized with manganese (Mn) in the pinnae and pinnules, with the highest and lowest concentrations in the necrotic lesions and veins, respectively (Fig. 7). ${ }^{49}$ These observations are important for a better understanding of the physiological mechanisms underlying REE hyperaccumulation.

The cultivation of REE metal crops on REEenriched soils leads to the production of REEenriched biomass. In a phyto-extraction operation, this enriched biomass is subjected to a series of processes to recover valuable metals. Conventional metal extraction techniques from hyperaccumulator plants are mainly based on biomass incineration, followed by chemical leaching and purification steps. ${ }^{50}$ Recent innovations in process developments have led to the direct leaching of dried biomass without incineration. Two innovative REE recovery processes from REE-enriched biomass of $D$. linearis have been established, and neither process requires biomass incineration. ${ }^{51,52}$ These recovery processes are an enhanced ion-exchange leaching process and a three-step process involving extraction, oxalate precipitation, and calcination. In both methods, the critical first steps are biomass drying and grinding.

Table II. Comparison of various methods for separation of individual rare earth elements

\begin{tabular}{|c|c|c|c|}
\hline Methods & Operations/reagents & Technical characteristics & Technical challenges \\
\hline $\begin{array}{l}\text { Fractional } \\
\text { crystallization }\end{array}$ & $\begin{array}{l}\text { Multi-stage recrystallization; } \\
\text { evaporation crystallization }\end{array}$ & $\begin{array}{l}\text { Forming double nitrate REE salts } \\
\qquad \mathrm{RE}\left(\mathrm{NO}_{3}\right)_{2} \cdot 2 \mathrm{NH}_{4} \mathrm{NO}_{3} \cdot 4 \mathrm{H}_{2} \mathrm{O}\end{array}$ & $\begin{array}{l}\text { It is slow and tedious for heavy } \\
\text { REE separations due to their } \\
\text { similar solubilities }\end{array}$ \\
\hline $\begin{array}{l}\text { Fractional } \\
\text { precipitation }\end{array}$ & $\begin{array}{c}\text { Adding chemical reagents to form } \\
\text { REE compounds with various sol- } \\
\text { ubilities }\end{array}$ & $\begin{array}{l}\text { Forming REE hydroxides or dou- } \\
\text { ble sulfate salts. } \\
\mathrm{RE}_{2}\left(\mathrm{SO}_{4}\right)_{3} \cdot \mathrm{Na}_{2} \mathrm{SO}_{4} \cdot \mathrm{nH}_{2} \mathrm{O}\end{array}$ & $\begin{array}{c}\text { The procedures are inefficient } \\
\text { and laborious. The product } \\
\text { purity is relatively low }\end{array}$ \\
\hline Ion exchange & $\begin{array}{c}\text { Strong and weak acidic cation } \\
\text { exchange resin }\end{array}$ & $\begin{array}{l}\text { Displacement chromatography } \\
\text { and elution chromatography; } \\
\text { selective elution by EDTA, DTPA, } \\
\text { DCTA, citrate, etc. }\end{array}$ & $\begin{array}{l}\text { Low recoveries for REE; high } \\
\text { water consumption; large } \\
\text { wastewater treatment }\end{array}$ \\
\hline $\begin{array}{l}\text { Solvent } \\
\text { extraction }\end{array}$ & $\begin{array}{l}\text { Organic extractants: phosphoric } \\
\text { acids (D2EHPA); carboxylic acids } \\
\text { (Versatic 911); solvating extrac- } \\
\text { tants (TBP); amines (Aliquat } 336 \text { ) }\end{array}$ & $\begin{array}{l}\text { Counter current flow scheme; } \\
\text { simultaneous recovery of U, heavy } \\
\text { REE and light REE with high } \\
\text { efficiency }\end{array}$ & $\begin{array}{l}\text { For producing multiple single } \\
\text { rare-earth products, hundreds } \\
\text { of stages of mixers and settlers } \\
\text { are required }\end{array}$ \\
\hline
\end{tabular}


The former recovery process relies on an enhanced ion-exchange leaching step carried out in $0.5 \mathrm{M}$ nitric acid solution. Once the ion-exchange resin is transferred into a column, REE purification is performed by percolating three solutions successively through a resin bed: two washing steps with water and $0.75 \mathrm{M}$ nitric acid to remove competing ions and one elution step using $3 \mathrm{M}$ nitric acid. These operations lead to $80 \%$ REE purity and $78 \%$ REE recovery. ${ }^{51}$ The second recovery process involves three steps: (1) extraction of REEs from the dried and powdered biomass by leaching with a solution containing an acid (e.g., sulfuric acid) and/ or complexing agents (e.g., ethylenediaminetetraacetic acid), (2) precipitation of REE with oxalate, and (3) calcination to prepare REO. These processes lead to $>80 \%$ REE purity and a recovery of a solid composed of 52 wt.\% REE, translating to an REE concentration factor from soil to final solid of $2500 .{ }^{52}$

\section{Microbial Biotechnological Approaches for Processing REE}

Microorganisms that are able to utilize minerals as a source of nutrients and/or energy can be used in 'bioprocessing' approaches for metal recovery from minerals, including supporting enhanced plant uptake (see above). Some of the benefits of bioprocessing compared to traditional processing include lower temperatures and pressures than conventional extraction approaches, reduced energy consumption, and fewer $\mathrm{CO}_{2}$ emissions. ${ }^{53}$

\section{Bioprocessing of Metal Sulfides}

Traditional bioprocessing (also referred to as bioleaching) is based on the bacterial oxidation of ferrous iron (Eq. 13) and the biotic (Eq. 14) and abiotic (Eq. 15) oxidation of reduced sulfur compounds, to generate acid and to release elements

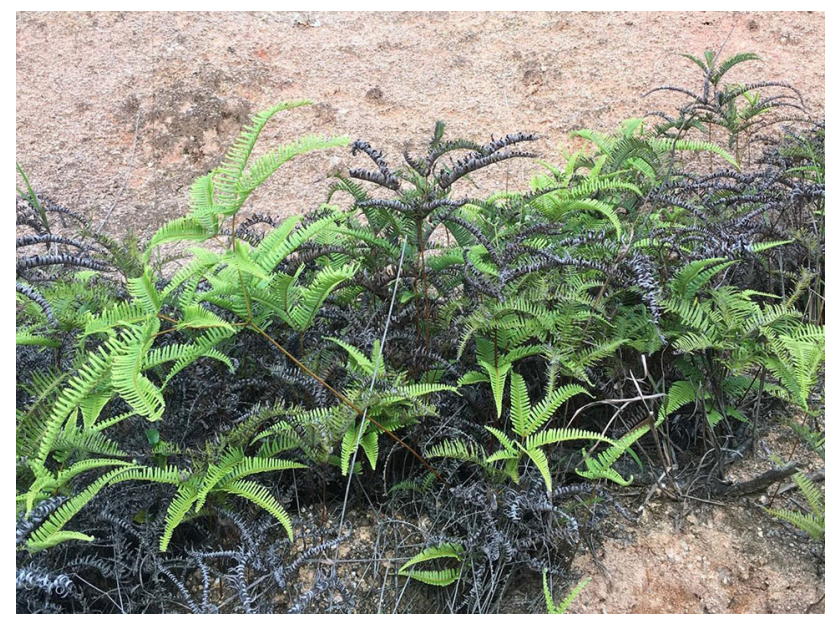

Fig. 6. Dicranopteris linearis growing on REE-rich mine tailings in southern China. Image courtesy of Wen-Shen Liu, School of Environmental Science and Engineering, Sun Yat-sen University, China typically associated with sulfide minerals. ${ }^{53}$ The oxidation of reduced iron and sulfur in natural, acid rock drainage environments ${ }^{54}$ produces sulfuric acid, which can promote the solubilization of a wide range of metals, including REE. In these systems, the biooxidation of ferrous iron (reaction 13) catalyses the abiotic oxidation of sulfur in pyrite, regenerating ferrous iron as the source of energy for these sulfuric acid generating bacteria (reaction 15):

$$
\begin{gathered}
\mathrm{Fe}^{2+}+1 / 2 \mathrm{H}^{+}+1 / 4 \mathrm{O}_{2} \rightarrow \mathrm{Fe}^{3+}+1 / 2 \mathrm{H}_{2} \mathrm{O} \text { (biological) } \\
\mathrm{S}^{0}+\mathrm{H}_{2} \mathrm{O}+11 / 2 \mathrm{O}_{2} \rightarrow \mathrm{H}_{2} \mathrm{SO}_{4}(\text { biological) } \\
14 \mathrm{Fe}^{3+}+\mathrm{FeS}_{2(\mathrm{~s})}+8 \mathrm{H}_{2} \mathrm{O} \\
\rightarrow 15 \mathrm{Fe}^{2+}+2 \mathrm{SO}_{4}^{2-}+16 \mathrm{H}^{+}(\text {abiotic })
\end{gathered}
$$

These linked bio(geo)chemical reactions are the basis for the biohydrometallurgical processing of sulfide ores. ${ }^{55}$ In the sense that these microbial processes generate copious amounts of acid, they are also fundamentally similar to natural supergene weathering processes that result in metal enrichment, and to chemical REE extraction methods that leverage acid-driven mineral dissolution.

\section{REE-Bearing Phosphorites}

Since the reduced iron and sulfur compounds that drive traditional bioleaching are not found in phosphorite REE ore bodies, bioleaching approaches for REE recovery from phosphorites focus instead on microbial phosphate solubilization. ${ }^{56}$ REE-bearing phosphorites represent massive sources of $\mathrm{P}$, an essential and often limiting, nutrient for the growth of bacteria. ${ }^{57}$ Microbial phosphate solubilization is a heterotrophic process, which therefore relies on the provision of an external carbon source, usually a sugar. Microbial fermentation of sugar produces a variety of organic acids (e.g., acetic, citric, formic, oxalic, and pyruvic) that drive REE leaching and stimulate growth of indigenous microorganisms on the ore, further promoting mineral dissolution. ${ }^{56}$

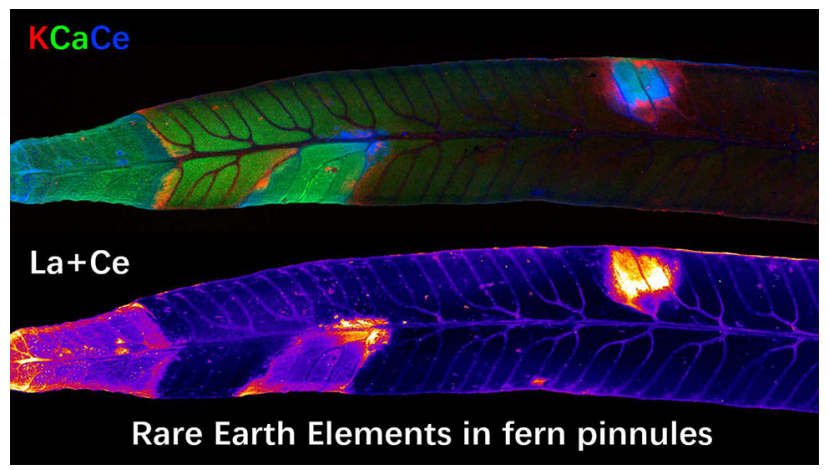

Fig. 7. Distribution of REE and major elements in fern pinnules. Reprinted with permission of Ref. 49 
The efficiency of REE recovery from microbial phosphate solubilization varies widely depending on the organism(s) used and the ore type. Recoveries of 20-70\% REE from red mud have been shown with a pure culture of the phosphate-solubilizing fungus Penicillium tricolor; ${ }^{58}$ however, only $0.13 \%$ of $\mathrm{Ce}$ from monazite ore was recovered using phosphate-solubilizing Acetobacter aceti ${ }^{59}$ Recent work has demonstrated that adding a phosphatesolubilizing pure culture and carbon source to nonsterile ores can double REE leaching and is more efficient than using either the pure culture or the indigenous consortium alone. ${ }^{60}$

\section{REE in Laterites; Metal Oxides}

Where REE are associated with lateritic ore, microbial processes that lead to the dissolution of ferric oxides can be harnessed to catalyze the release of REE into solution. Metal-reducing microorganisms may function at circumneutral $\mathrm{pH}$ under anerobic conditions, or at acidic $\mathrm{pH}$ under aerobic or anerobic conditions.

Acidic, anerobic processing. Acidic bioleaching for recovery of metals from goethite-rich ores has been commercially demonstrated under anerobic conditions, aerobic conditions, and a combination of sequential aerobic/anerobic conditions. ${ }^{61-64}$ Microorganisms involved in these processes are typically the same as those used in commercial bioleaching of metal sulfides. However, in this case, the process is reversed and ferric iron in goethite serves as an electron acceptor for microbial respiration. Under acidic, anerobic conditions, the electron donor may be elemental sulfur, hydrogen or a carbon source, and the overall process is acidconsuming, i.e., the Ferredox reaction (Eq. 16): ${ }^{61}$

$$
6 \mathrm{FeOOH}+\mathrm{S}^{0}+10 \mathrm{H}^{+} \rightarrow 6 \mathrm{Fe}^{2+}+8 \mathrm{H}_{2} \mathrm{O}+\mathrm{SO}_{4}^{2-}
$$

Using Acidithiobacillus ferrooxidans, metal recoveries of up to $70 \%$ for $\mathrm{Ni}$ have been observed for acidic anaerobic reductive dissolution of laterites, compared to $10 \%$ recovery under completely aerobic conditions. ${ }^{62}$ Required inputs for the process are acid, elemental sulfur, and a nitrogen headspace. While capex is much lower for microbial reductive dissolution of laterite ores than conventional processing approaches, operational costs, particularly for acid, remain high. ${ }^{64}$ Marrero et al., ${ }^{64,65}$ recently demonstrated that aerobic reductive dissolution of laterite is possible using Acidithiobacillus thiooxidans at extremely low $\mathrm{pH}(0.8)$, and that dissolution proceeds via acidolysis (Eq. 17); acid produced from Eq. 18 and subsequent bioreduction of ferric iron by an unknown mechanism (written as an iron-reducing half-reaction; Eq. 19 releases metal into solution. Aerobic reductive dissolution, or indeed a combination of anerobic and aerobic reductive dissolution using a co-culture of $A$. ferrooxidans and $A$. thiooxidans, offers substantial cost-saving compared to anerobic acidic reductive dissolution (Ferredox process), because efficient aerobic sulfur oxidation generates acid, reducing the overall acid inputs required. ${ }^{64}$ Conceivably, REE associated with iron oxides in laterite systems should be recoverable via the same bioprocessing routes.

$$
\begin{gathered}
\mathrm{FeOOH}+3 \mathrm{H}^{+} \rightarrow \mathrm{Fe}^{3+}+2 \mathrm{H}_{2} \mathrm{O} \\
\mathrm{S}^{0}+\mathrm{H}_{2} \mathrm{O}+1.5 \mathrm{O}_{2} \rightarrow \mathrm{SO}_{4}^{2-}+2 \mathrm{H}^{+} \\
\mathrm{Fe}^{3+}+8 \mathrm{e}^{-} \rightarrow \mathrm{Fe}^{2+}
\end{gathered}
$$

\section{Organic Acid Processing}

Under circumneutral $\mathrm{pH}$ conditions, metal recovery from laterites has been demonstrated at laboratory scale, using a range of aerobic fungi, mainly Aspergillus and Penicillum spp. ${ }^{66}$ Organic acids produced by the fungi during growth aid in mineral dissolution and metal solubilization from laterites. Benefits of this biotechnology for low-grade ores include the use of low-cost carbon sources to drive the process. However, while laboratory-scale demonstrations have indicated promising results for fungal bioleaching of laterites, the technology is inefficient in stirred tank reactors and is likely more amenable for static heap leach technologies. ${ }^{67,68}$

\section{Circumneutral pH, Anerobic Processing}

Microbial reduction of iron oxides under circumneutral, anerobic conditions is another opportunity for development of efficient biotechnologies to extract metals from laterites. A range of microorganisms can use iron oxides as an electron acceptor during growth under circumneutral, anerobic conditions (e.g., Eq. 20). Dissolution of the iron oxide minerals results in the release of associated metals from the mineral structure. ${ }^{69}$ However, the challenge with anerobic processing of laterites at circumneutral $\mathrm{pH}$ is that typical neutrophilic iron reducing bacteria (e.g., Geobacter sp., Shewanella sp.) do not reduce crystalline iron oxides (e.g., goethite and hematite) particularly well. Recent research has indicated that anerobic fermentation is an effective mechanism for microbial reduction of crystalline iron oxides. ${ }^{70,71}$ Anerobic fermentationdriven dissolution of goethite has been investigated in iron ore systems, and is currently being developed as biotechnology for accelerated post-mining remediation. ${ }^{70}$ The same principles that result in microbial goethite dissolution in those systems could be harnessed for dissolution of laterites and the mobilization of associated REE from the laterite structure. The major input into such a system would be a carbon source (e.g., glucose; Eq. 21), although the technology would conceivably be more efficient 
in controlled stirred reactors under a nitrogen headspace, which is an avenue for future investigation.

$$
\begin{aligned}
8 \mathrm{Fe}(\mathrm{OH})_{3}+\mathrm{CH}_{3} \mathrm{COOH} \rightarrow & 8 \mathrm{Fe}^{2+}+2 \mathrm{CO}_{2}+6 \mathrm{H}_{2} \mathrm{O} \\
& +16 \mathrm{OH}^{-}
\end{aligned}
$$

$$
\begin{array}{r}
\mathrm{C}_{6} \mathrm{H}_{12} \mathrm{O}_{6}+24 \mathrm{FeOOH}+48 \mathrm{H}^{+} \\
\rightarrow 24 \mathrm{Fe}^{2+}+42 \mathrm{H}_{2} \mathrm{O}+6 \mathrm{CO}_{2}
\end{array}
$$

\section{POTENTIAL OPTIONS FOR RECOVERING REE FROM MARY KATHLEEN TAILINGS}

The Mary Kathleen tailings REE deposit provides an excellent example of a challenge faced in many localities undergoing re-examination for extraction of previously unimportant and now critical elements. The workflow presented in this contribution has described the ore characteristics and the nature of previous processing, and has reviewed several conventional and non-conventional approaches to recovery of REE from the Mary Kathleen tailings. Criteria for assessment and prioritisation of treatment options could include: (1) the ability of the process to extract REE; (2) the practicality and cost of applying the process; (3) the ability of the process to selectively recover REE; and (4) the contribution of the process to remediation as opposed to further contamination.

In terms of conventional approaches, the amenability of the Mary Kathleen tailings to physical beneficiation to increase the concentration of REE in the (bio)chemical process feedstock should be established. However, physical processing may be challenging, given the similar surface properties and density of the REE hosts and gangue minerals. From a biogeochemical perspective, the fine-grained nature of the tailings $(<200 \mu \mathrm{m})$ and the solubilization and precipitation of low levels of REE with iron oxides below the tailings demonstrates that weathering of REE from the Mary Kathleen tailings is possible. For enhanced chemical leaching, sulfuric acid should be considered in the first instance as it is low cost relative to hydrochloric and nitric and should be available due to proximity to local sulfide smelters that remove the sulfur dioxide from process off-gas by converting it to sulfuric acid. A range of acid leaching conditions should be trialled to determine the REE-specific acid requirements. It may be advantageous that the tailings material has already been through an acid leaching process that would have dissolved the more reactive gangue minerals, allowing further weathering to release the REE. Alkaline processes are likely unfeasible due to the presence of reactive silicate minerals.
The accessory sulfide mineralogy at Mary Kathleen, ${ }^{72}$ e.g., pyrite, chalcopyrite, and pyrrhotite, is also undergoing oxidation and acid generation. ${ }^{25}$ Gleaning from these natural processes, it seems that traditional bioleaching approaches which harness microbially-driven sulfide dissolution and acid generation could be applicable to the Mary Kathleen tailings for extraction of REE associated with the tailings. This requires further investigation to establish the biooxidation reaction kinetics and associated REE extraction kinetics and extent. Biologically generated acids can in principle be less expensive than purchasing acid, although sulfuric acid is being produced in the vicinity of Mary Kathleen.

Combining phyto-extraction with microbial weathering can also be considered to recover REE. If achievable, this approach could provide advantages in terms of reaction selectivity and separation of REE from each other and from other impurity elements. This would be advantageous as the separation and purification of REE is typically a costly part of the operation. In developing effective phytoextraction at the Mary Kathleen tailings facility: (1) appropriate soil construction (e.g., removal of the 1$\mathrm{m}$ inert capping) is required, (2) the phyto-available REE need to be assessed, and (3) screening for potential locally adapted REE metal crops is required. In identifying local REE metal crops, the widespread Australian plant family, the Proteaceae, is of specific interest, because: (1) they produce large amounts of carboxylic acids to lower the rhizosphere $\mathrm{pH}$ thereby promoting solubility of metals; (2) they have a strong potential to accumulate $\mathrm{Al}$ and $\mathrm{Mn}$; and (3) they are typically drought-tolerant. Other potential species have been introduced into Australia including Phytolacca americana (synonym $P$. acinosa), first identified as a Mn hyperaccumulator but can also accumulate REE. ${ }^{73}$ This ubiquitous weed grows along roadsides and disturbed areas in its native range in the southeastern United States, and is now distributed worldwide. It is also a declared weed in Queensland. It is a fast-growing and high biomass-producing plant that can reach $3 \mathrm{~m}$ in height. When growing on REE-enriched soils in China, it can attain up to $1040 \mu \mathrm{g} \mathrm{g}^{-1} \mathrm{REE}$. Recently, several studies have investigated the translocation and fractionation of REE in P. americana which have shown a higher translocation of HREE in the leaves compared to LREE, while more LREE accumulated in the roots and stems. ${ }^{74,75}$ It is unknown how this species performs in extracting REE from Australian REE-rich substrates, provided appropriate weed risk management is undertaken. However, its fast growth rate makes it an attractive model to study the key physiological mechanisms involved with REE accumulation. Alternatively, Dicranopteris linearis also occurs in Queensland, and may be developed as an REE metal crop, 
although it would first need to be established whether the Australian populations will hyperaccumulate REE.

In summary, this preliminary analysis suggests that the most effective flowsheet for recovery of REE from Mary Kathleen tailings may actually draw from a combination of hydrometallurgical processes, bioleaching, and phyto-extraction approaches, the details of which are best elucidated using a multidisciplinary analysis which draws on the best possible characterization of the mineralized material.

\section{ACKNOWLEDGEMENTS}

We gratefully acknowledge the funding for this research from the Queensland Department of Natural Resources, Mines and Energy as part of the project "Extracting Queensland's Rare Earth Elements Sustainably".

\section{CONFLICT OF INTEREST}

On behalf of all authors, the corresponding author states that there is no conflict of interest.

\section{OPEN ACCESS}

This article is licensed under a Creative Commons Attribution 4.0 International License, which permits use, sharing, adaptation, distribution and reproduction in any medium or format, as long as you give appropriate credit to the original author(s) and the source, provide a link to the Creative Commons licence, and indicate if changes were made. The images or other third party material in this article are included in the article's Creative Commons licence, unless indicated otherwise in a credit line to the material. If material is not included in the article's Creative Commons licence and your intended use is not permitted by statutory regulation or exceeds the permitted use, you will need to obtain permission directly from the copyright holder. To view a copy of this licence, visit $h$ ttp://creativecommons.org/licenses/by/4.0/.

\section{REFERENCES}

1. J. Gambogi, U.S. Geological Survey. https://pubs.usgs.gov/ periodicals/mcs2020/mcs2020-rare-earths.pdf, 2020.

2. N. Dushyantha, N. Batapola, I.M.S.K. Ilankoon, S. Rohitha, R. Premasiri, B. Abeysinghe, N. Ratnayake, and K. Dissanayake, Ore Geol. Rev. 122 (2020).

3. K. Binnemans, P.T. Jones, B. Blanpain, T. Van Gerven, Y. Yang, A. Walton, and M. Buchert, J. Clean. Prod. 51, 1 (2013).

4. P. Koltun and A. Tharumarajah, ISRN Metall. 2014, 1 (2014).

5. D. Hoatson, S. Jaireth, and Y. Miezitis, Geoscience Australia, Canberra, 2011.

6. S.M. Jowitt, T.T. Werner, Z. Weng, and G.M. Mudd, Curr. Opin. Green Sustain. Chem. 13, 1 (2018).

7. M. Edahbi, B. Plante, M. Benzaazoua, L. Kormos, and M. Pelletier, Minerals 8 (2018.).

8. M. Edahbi, B. Plante, and M. Benzaazoua, J. Clean. Prod. 212, 1232 (2019).
9. S. Krneta, C.L. Ciobanu, N.J. Cook, K. Ehrig, and A. Kontonikas-Charos, Minerals 7, 135 (2017).

10. D.S. Schmandt, N.J. Cook, C.L. Ciobanu, K. Ehrig, B.P. Wade, S. Gilbert, and V.S. Kamenetsky, Minerals 7, 202 (2017).

11. S. Peelman, Z.H.I. Sun, J. Sietsma, and Y. Yang,. Rare Metal Technology, S. Alam, et al. ed. (Berlin: Springer, 2016).

12. Z. Weng, S. Jowitt, G. Mudd, and N. Haque, Econ. Geol. 110, 1925 (2015).

13. M. Costelloe, Environmental Review of the Mary Kathleen Uranium Mine, Masters Thesis, James Cook University, 2003.

14. G.M. Derrick, BMR J. Austral. Geol. Geophys. 2, 123 (1977).

15. D. McKay and Y. Miezitis, in Mineral Resource Report 1 (Canberra: GSO Geoscience Australia, 2001).

16. R.W. Page, Econ. Geol. 78, 838 (1983).

17. N.H.S. Oliver, P.J. Pearson, R.J. Holcombe, and A. Ord, Austral. J. Earth Sci. 46, 467 (1999).

18. M. Solomon and D.I. Groves, The geology and origin of Australia's mineral deposits. Oxford Monographs on Geology and Geophysics, vol. 24. (Oxford: Oxford University Press, 1994).

19. Chinalco-Yunnan-Copper-Resources-Ltd. 2012.

20. B.W. Hawkins, in Economic Geology of Australia and Papua New Guinea, Monograph 5, C.L. Knight ed. (Melbourne: The Australasian Institute of Mining and Metallurgy, 1975).

21. F.R. Hartley, in Symposium on Uranium in Australia. The AusIMM. Rum Jungle, Northern Territory, Australia, 1968.

22. J. Thomas, in The AusIMM North West Queensland Branch Mill Operators Conference, 1978, pp. 275-284.

23. CSA-Global-Pty and Outback-Ecology, in A report submitted to the Department of Natural Resources and Mines, Queensland, 2013.

24. R.W. Hubery, in Mining and metallurgical practices in Australasia, J.T. Woodcock, ed. (Victoria, Australia: The Australasian institute of mining and metallurgy,1980), pp. 533-536.

25. B.G. Lottermoser and P.M. Ashley, J. Geochem. Explor. 85, 119 (2005).

26. M.C. Vegafria, Geochemical Pathways of Contaminants through Weathering of Uranium Tailings, $\mathrm{PhD}$ Thesis, The University of Queensland, 2018.

27. S. Jaireth, D.M. Hoatson, and Y. Miezitis, Ore Geol. Rev. 62,72 (2014)

28. F. Habashi, Can. Metall. Q. 52, 224 (2013).

29. N. Krishnamurthy and C.K. Gupta, Extractive Metallurgy of Rare Earths, 2nd ed. (Boca Raton: CRC Press, 2016).

30. P.A. Guy, W.J. Bruckard, and M.J. Vaisey, Seventh Mill Operators' Conference (Western Australia: Kalgoorlie, 2000).

31. C.K. Gupta and N. Krishnamurthy, Int. Mater. Rev. 37, 197 (1992).

32. J. Lucas, P. Lucas, T.L. Mercier, A. Rollat, and W. Davenport, Rare Earths Science, Technology, Production and Use (Amsterdam: Elsevier, 2015).

33. J. Demol, E. Ho, K. Soldenhoff, and G. Senanayake, $H y$ drometallurgy 188, 123 (2019).

34. J. Demol, E. Ho, and G. Senanayake, Hydrometallurgy 179, 254 (2018).

35. D. Qi, Extraction of Rare Earths From RE Concentrates. Hydrometallurgy of Rare Earths (Amsterdam: Elsevier, 2018).

36. W. Brugger and E. Greinacher, JOM 19, 32 (1967).

37. R. Chi, J. Tian, X. Luo, Z. Xu, and Z. He, Nonferr. Metals Sci. Eng. 3, 1 (2012) (in Chinese).

38. J. Zhang, B. Zhao, and B. Schreiner, Separation Hydrometallurgy of Rare Earth Elements (Cham: Springer, 2016).

39. F. Xie, T.A. Zhang, D. Dreisinger, and F. Doyle, Miner. Eng. 56, 10 (2014). 
40. N.N. Hidayah and S.Z. Abidin, Miner. Eng. 121, 146 (2018).

41. R.L. Chaney, J.S. Angle, C.L. Broadhurst, C.A. Peters, R.V. Tappero, and D.L. Sparks, J. Environ. Qual. 36, 1429 (2007).

42. P.N. Nkrumah, G. Echevarria, P.D. Erskine, and A. van der Ent, in Extracting Innovations: Mining, Energy, and Technological Change in the Digital Age, eds. M.J. Clifford, et al. (Boca Raton: CRC, 2018), pp. 313-324.

43. A. van der Ent, A.J.M. Baker, R.D. Reeves, R.L. Chaney, C.W.N. Anderson, J.A. Meech, P.D. Erskine, M.-O. Simonnot, J. Vaughan, J.L. Morel, G. Echevarria, B. Fogliani, Q. Rongliang, and D.R. Mulligan, Environ. Sci. Technol. 49, 4773 (2015).

44. A. Corzo Remigio, R.L. Chaney, A.J.M. Baker, M. Edraki, P.D. Erskine, G. Echevarria, and A. van der Ent, Plant Soil 449, 11 (2020).

45. J.L. Morel, G. Echevarria, A. van der Ent, and A.J. Baker, in Agromining: Farming for Metals. (Berlin: Springer, 2018), pp. 309-312.

46. R.L. Chaney, A.J. Baker, and J.L. Morel, in Agromining: Farming for Metals. (Berlin: Springer, 2018), pp. 1-17.

47. P.N. Nkrumah, R. Tisserand, R.L. Chaney, A.J.M. Baker, J.L. Morel, R. Goudon, P.D. Erskine, G. Echevarria, and A. van der Ent, J. Geochem. Explor. 198, 114 (2019).

48. C. Liu, M. Yuan, W.-S. Liu, M.-N. Guo, H. Huot, Y.-T. Tang, B. Laubie, M.-O. Simonnot, J.L. Morel, and R.-L. Qiu, in Agromining: Farming for Metals (Berlin: Springer, 2018), pp. 297-308.

49. W.-S. Liu, A. van der Ent, P.D. Erskine, J.L. Morel, G. Echevarria, K.M. Spiers, E. Montargès-Pelletier, R.-L. Qiu, and Y.-T. Tang, Environ. Sci. Technol. 54, 2287 (2020).

50. R. Barbaroux, G. Mercier, J.F. Blais, J.L. Morel, and M.O. Simonnot, Separ. Purif. Technol 83, 57 (2011).

51. Z. Chour, B. Laubie, J.L. Morel, Y. Tang, R. Qiu, M.-O. Simonnot, and L. Muhr, Chem. Eng. Process.-Process. Intensif. 130, 208 (2018).

52. Z. Chour, B. Laubie, J.L. Morel, Y.-T. Tang, M.-O. Simonnot, and L. Muhr, J. Environ. Chem. Eng. 8, 103961 (2020).

53. D.B. Johnson, Curr. Opin. Biotechnol. 30, 24 (2014).

54. D.K. Nordstrom and G. Southam, Rev. Mineral. Geochem. 35,361 (1997).

55. D.E. Rawlings, H. Tributsch, and G.S. Hansford, Microbiology 145, 5 (1999).

56. M.K. Corbett and E.L. Watkin, Microbiol. Austral. 39, 50 (2018).

57. J.R. Rogers and P.C. Bennett, Chem. Geol. 203, 91 (2004).

58. Y. Qu and B. Lian, Bioresour. Technol. 136, 16 (2013).

59. D. Shin, J. Kim, B. Kim, J. Jeong, and J. Lee, Minerals 5, 189 (2015).

60. M.K. Corbett, J.J. Eksteen, X.Z. Niu, and E.L. Watkin, Solid State Phenom. 262, 294 (2017).

61. C.A. du Plessis, W. Slabbert, K.B. Hallberg, and D.B. Johnson, Hydrometallurgy 109, 221 (2011).

62. K.B. Hallberg, B.M. Grail, C.A.d. Plessis, and D.B. Johnson, Miner. Eng. 24, 620 (2011).

63. D.B. Johnson and C.A. du Plessis, Miner. Eng. 75, 2 (2015).

64. J. Marrero, O. Coto, S. Goldmann, T. Graupner, and A. Schippers, Environ. Sci. Technol. 49, 6674 (2015).

65. J. Marrero, O. Coto, and A. Schippers, Hydrometallurgy 168, 49 (2017).

66. S.K. Behera and A.F. Mulaba-Bafubiandi, Korean J. Chem. Eng. 32, 1447 (2015).

67. K.A.K. Alibhai, A.W.L. Dudeney, D.J. Leak, S. Agatzini, P. Tzeferis, and F.E.M.S. Microbiol, Rev. 11, 87 (1993).

68. J.A. Tang and M. Valix, Miner. Eng. 19, 1274 (2006).

69. G.M. Gadd, Microbiology 156, 609 (2010).

70. E.J. Gagen, J. Zaugg, G.W. Tyson, and G. Southam, Front. Microbiol. 10, 2938 (2019).

71. C. Lentini, S. Wankel, and C. Hansel, Front. Microbiol. 3 (2012).

72. R.S. Matheson and R.A. Searl, Econ. Geol. 51, 528 (1956).

73. S. Xue, J. Wang, X. Zhou, H. Liu, and Y. Chen, Acta Ecol. Sin. 30, 335 (2010).
74. M. Yuan, M.-N. Guo, W.-S. Liu, C. Liu, A. van der Ent, J.L. Morel, H. Huot, W.-Y. Zhao, X.-G. Wei, R.-L. Qiu, and Y.-T. Tang, Plant Soil 421, 67 (2017).

75. M. Yuan, C. Liu, W.-S. Liu, M.-N. Guo, J.L. Morel, H. Huot, H.-J. Yu, Y.-T. Tang, and R.-L. Qiu, Int. J. Phytoremed. 20, 415 (2018)

76. T.E. Amer, W.M. Abdella, G.M.A. Wahab, and E.M. ElSheikh, Int. J. Miner. Process. 125, 106 (2013).

77. R. Panda, A. Kumari, M.K. Jha, J. Hait, V. Kumar, J. Rajesh Kumar, and J.Y. Lee, J. Ind. Eng. Chem. 20, 2035 (2014).

78. Y. Yao, H. Li, and Y. Li, Multipurpose Utilization of Mineral Resources. 7-11 (1999).

79. Y. Xu, H. Liu, Z. Meng, J. Cui, W. Zhao, and L. Li, J. Rare Earths 30, 155 (2012).

80. P. Alex, A.K. Suri, and C.K. Gupta, Hydrometallurgy 50, 331 (1998).

81. A. Kumari, R. Panda, M.K. Jha, J.R. Kumar, and J.Y. Lee, Miner. Eng. 79, 102 (2015).

82. R.R. Merritt, J. Less Common Metals 166, 211 (1990).

83. A. Kumari, R. Panda, M.K. Jha, J.Y. Lee, J.R. Kumar, and V. Kumar, J. Ind. Eng. Chem. 21, 696 (2015).

84. J. Zhao, F. Pan, and H. Liu, Separ. Purif. Technol. 168, 161 (2016).

85. C. Du, M. Li, S. Liu, H. Chang, and Y. Hu, Hydrometall. China 29, 1 (2010) (in Chinese).

86. J.G. Parker, C.T. Baroch, and J.W. Adams. The Rare-earth Elements, Yttrium, and Thorium. A Materials Survey (Washington, D.C.: Bureau of Mines, 1971).

87. G. Zhang and X. Huang, Rare Metals 21, 193 (1997) (in Chinese).

88. J. Zhou, Y. Xu, and M. Chen, Chin. Rare Earths 21, 19 (2000) (in Chinese).

89. M. Kul, Y. Topkaya, and İ. Karakaya, Hydrometallurgy 93 , 129 (2008).

90. X.-W. Huang, Z.-Q. Long, L.-S. Wang, and Z.-Y. Feng, Rare Met. 34, 215 (2015).

91. N.T. Hung, L.B. Thuan, T.C. Thanh, M. Watanabe, H. Nhuan, K. Do Van, N.T. Thuy, N. Van Tung, N. Aoyagi, D.T.T. Tra, N.T. Minh, M.K. Jha, J.-Y. Lee, and R.K. Jyothi, Hydrometallurgy 191, 105195 (2020).

92. J. Ni and G. Hong, Chin. Rare Earths 11, 36 (1990) (in Chinese)

93. V.D. Kosynkin, S.D. Moiseev, C.H. Peterson, and B.V. Nikipelov, J. Alloys Compds 192, 118 (1993).

94. D.B. Dreisinger, J.D. Clucas, N. Verbaan, T. Grammatikopoulos, M. Aghamirian, and C. Forstner, in Proceedings of the 51st Conference of Metallurgists (COM 2012), eds. J.R. Goode, G. Moldoveanu, and M.S. Rayat. (Niagara, Ontario, Canada: Canadian Institute of Mining, Metallurgy and Petroleum, 2012), pp. 81-94.

95. G. Nazari and B. Krysa, in Proceedings of the 52nd Conference of Metallurgists (COM 2013), Eds. I.M. London, et al. (Montreal, Quebec, Canada: Canadian Institute of Mining, Metallurgy and Petroleum, 2013), pp. 325-331.

96. H. Lim, D. Ibana, and J. Eksteen, J. Rare Earths 34, 908 (2016).

97. P. Davris, S. Stopic, E. Balomenos, D. Panias, I. Paspaliaris, and B. Friedrich, Miner. Eng. 108, 115 (2017).

98. P. Ribagnac, G.J.P. Deblonde, S.B. Blancher, L. Lengagne, L. Donati, C. Malimba, B. Courtaud, V. Weigel, and D. Beltrami, Separ. Purif. Technol. 189, 1 (2017).

99. O.M. El-Hussaini and M.A. Mahdy, Hydrometallurgy 64 219 (2002).

100. M.G. Baillie and J.D. Hayton, in 9th International Mineral Processing Congress, Institution of Mining and Metallurgy. (Czechoslovakia: Institution of Mining and Metallurgy (London), 1970), pp. 334-345.

101. X.-L. Feng, Z.-Q. Long, D.-L. Cui, L.-S. Wang, X.-W Huang, and G.-C. Zhang, Trans. Nonferr. Metals Soc. China 23, 849 (2013).

102. D. Zou, J. Chen, K. Li, and D. Li, ACS Omega 3, 17036 (2018).

103. M. Wang, M. Zeng, L. Wang, J. Zhou, D. Cui, Q. Wang, R. Weng, and X. Chen, J. Chin. Rare Earth Soc. 31, 148 (2013) (in Chinese). 
104. P.R. Kruesi and G. Duker, JOM 17, 847 (1965).

105. D. Voßenkaul, A. Birich, N. Müller, N. Stoltz, and B. Friedrich, J. Sustain. Metall. 3, 79 (2017).

106. Y. Pan, Hand Book of Extraction of Non-ferrous Metals (Rare Earth Extraction) (Beijing: Metallurgical Industry Press, 1993) (in Chinese).
107. G.A. Moldoveanu and V.G. Papangelakis, Mineralog. Mag. 80, 63 (2016).

Publisher's Note Springer Nature remains neutral with regard to jurisdictional claims in published maps and institutional affiliations. 